\title{
PENGARUH DISIPLIN KERJA DAN KOMPENSASI TERHADAP KINERJA PEGAWAI DENGAN DIMEDIASI VARIABEL MOTIVASI
}

\author{
Ilham ${ }^{1}$, I Nyoman Nugraha ${ }^{2}$, Amir Tengku Ramly ${ }^{3}$ \\ ${ }^{1}$ Magister Manajemen Sumber Daya Manusia, Universitas Terbuka \\ E-mail: ilham.kotabima2017@gmail.com \\ 2Fakultas Ekonomi, Universitas Mataram.E-mail: ibobid@yahoo.com \\ 3 Universitas Ibnu Chaldun Bogor. E-mail: amirtengku127@gmail.com
}

\begin{tabular}{|c|c|}
\hline ARTICLE INFO & ABSTRACT \\
\hline 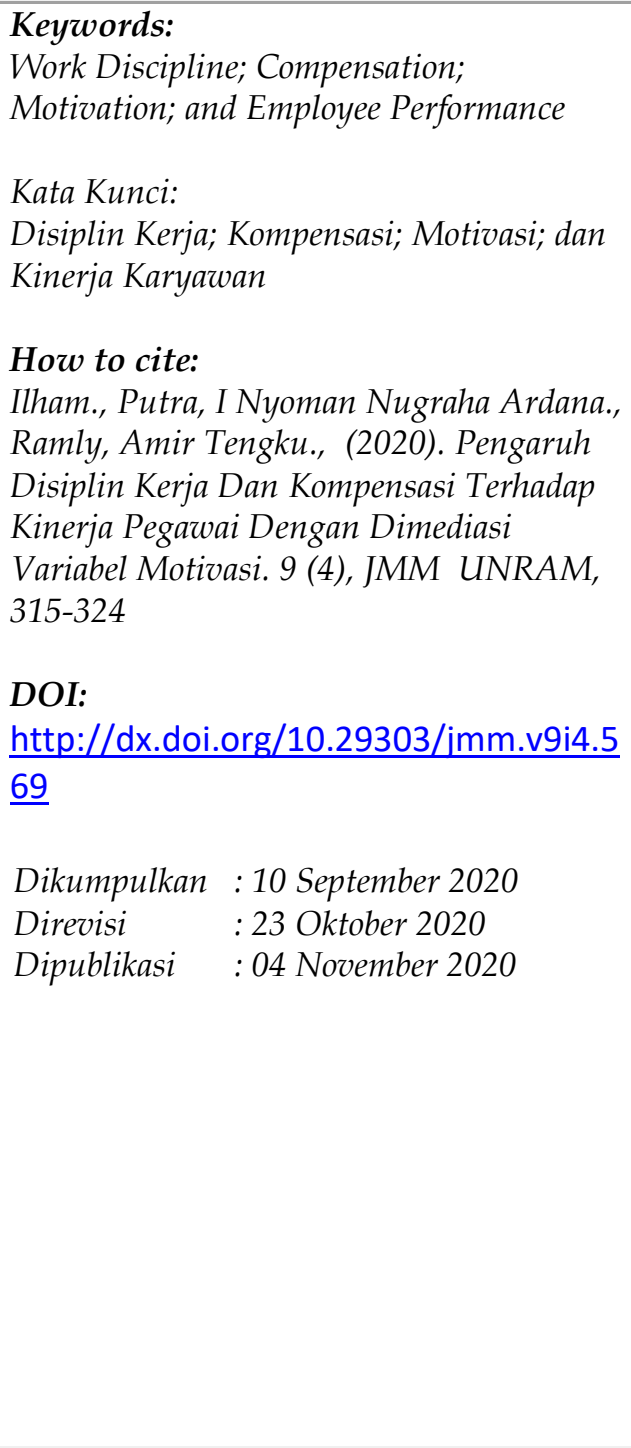 & $\begin{array}{l}\text { This research aimed to analyze the effect of work } \\
\text { discipline and compensation on employee } \\
\text { performance, and the effect of motivation as } \\
\text { intervening variabel. The population of research } \\
\text { amounted } 39 \text { employees. Thirthy four employees in } \\
\text { Investment And Integrated One Stop Services Of } \\
\text { Bima City were selected as the sample in this } \\
\text { research.The data collection technique used is a } \\
\text { questionnaire that has been tested for validity and } \\
\text { reliability, then tested using path analysis. From } \\
\text { the results data analysis produced several research } \\
\text { findings as follows work discipline has a positive } \\
\text { and significant effect on employee performance, } \\
\text { compensation has no effect on employee } \\
\text { performance, motivation does not effect in } \\
\text { employee performance, motivation can not mediate } \\
\text { the effect of work discipline with employee } \\
\text { performance, motivation can not mediate the effect } \\
\text { of work compensation with employee performance. } \\
\text { Penelitian ini bertujuan untuk menganalisis } \\
\text { pengaruh disiplin kerja dan kompensasi } \\
\text { terhadap kinerja karyawan, dan pengaruh } \\
\text { motivasi sebagai variabel intervening. } \\
\text { Populasi penelitian berjumlah } 39 \text { karyawan. } \\
\text { Sampel dalam penelitian ini adalah Tiga } \\
\text { Puluh Empat Pegawai Bidang Penanaman } \\
\text { Modal Dan Pelayanan Terpadu Satu Pintu } \\
\text { Kota Bima. Teknik pengumpulan data yang } \\
\text { digunakan adalah kuesioner yang telah diuji } \\
\text { validitas dan reliabilitasnya, kemudian diuji } \\
\text { menggunakan analisis jalur. Dari hasil analisis } \\
\text { data menghasilkan beberapa temuan } \\
\text { penelitian sebagai berikut disiplin kerja }\end{array}$ \\
\hline
\end{tabular}




\section{Jurnal Magister Manajemen Unram Vol. 9, No 4. November 2020 NATIONALYY ACCREDITED JOURNAL - DECREE NO. 21/E/KPT/2018}

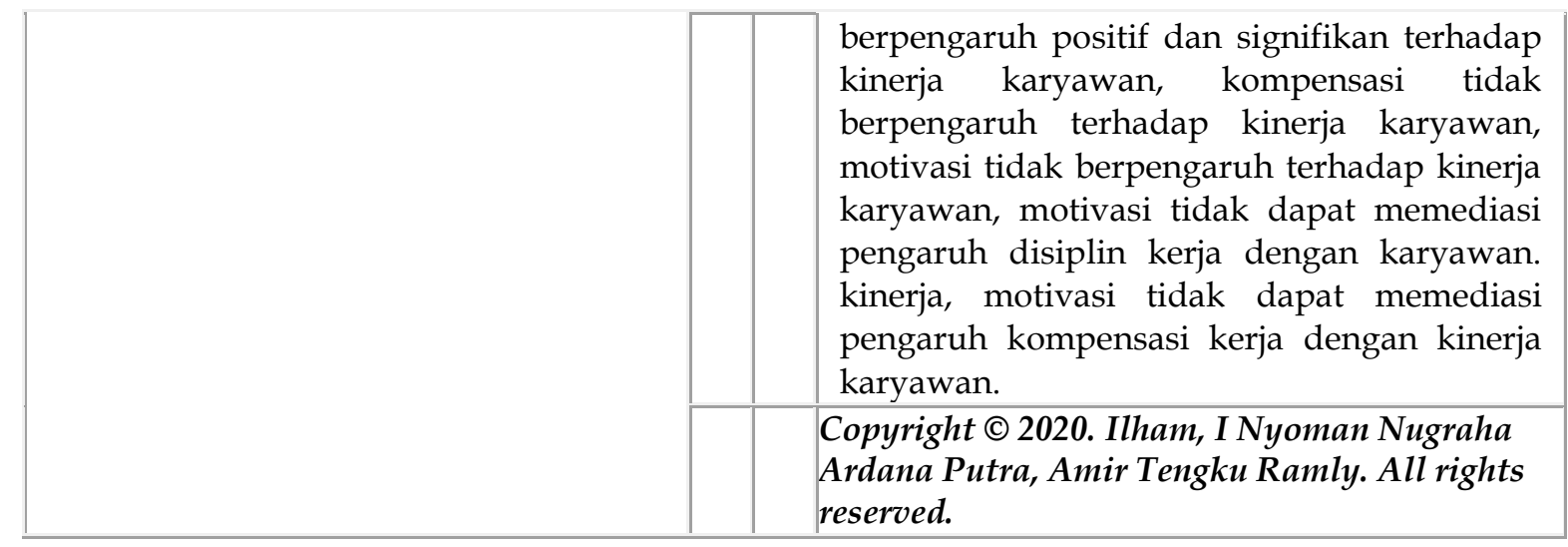

\section{PENDAHULUAN}

Salah satu tujuan seorang pegawai dalam bekerja adalah untuk memperoleh imbalan atau kompensasi. Dari kompensasi tersebut pegawai dapat memenuhi kebutuhan dan meningkatkan kesejahteraannya. Kompensasi penting bagi organisasi, karena programprogram konpensasi terutama ditujukan untuk mempertahankan sumber daya manusia, melalui pemberian gaji, upah, insentif, tunjangan dan kompensasi tidak langsung, menarik pegawai yang cakap masuk kedalam organisasi, mendorong pegawai untuk lebih berprestasi, mempertahankan pegawai produktif dan berkualitas agar tetap setia dengan organisasi.

Selain kompensasi, sumber daya manusia yang ada perlu dimotivasi agar dapat bekerja lebih giat dan berprestasi. Motivasi adalah dorongan kebutuhan dalam diri pegawai yang perlu dipenuhi agar pegawai tersebut dapat menyesuaikan diri terhadap lingkungannya (Mangkunegara, 2009)

Upaya peningkatan kinerja pegawai tidak terlepas dari kedisiplinan pegawai (Listianto, 2007). Disiplin adalah suatu sikap perbuatan dan tingkah laku yang harus sesuai dengan peraturan yang ada. Apabila pegawai tidak disiplin maka hasil kerja dan kegiatan rutin pegawai akan terganggu.

Terdapat perbedaan hasil penelitian terdahulu dimana menurut Mahardika, dkk (2016), disiplin kerja dan kompensasi memiliki pengaruh positif dan signifikan terhadap kinerja karyawan, sedangkan menurut Satedjo dan Kempa (2017) kompensasi berpengaruh signifikan terhadap kinerja karyawan, serta disiplin kerja tidak berpengaruh signifikan terhadap kinerja karyawan. Hasil penelitian Goda (2018), menunjukkan bahwa disiplin kerja mempengaruhi kinerja karyawan, sedangkan kompensasi dan motivasi tidak berpengaruh terhadap kinerja karyawan, dan disiplin kerja, kompensasi, serta motivasi kerja secara bersama-sama berpengaruh positif terhadap kinerja karyawan.

Fenomena yang terjadi saat ini adalah adanya indikasi terjadinya penurunan kinerja pegawai pada Dinas Penanaman Modal dan Pelayanan Terpadu Satu Pintu Kota Bima. Hal ini ditunjukkan dengan adanya penurunan jumlah izin yang diterbitkan, dimana jumlah izin yang diterbitkan pada Tahun 2017 sebanyak 2.586 izin sedangkan pada Tahun 2018 sebanyak 2.150 izin. Selain itu tingkat kedisiplinan pegawai juga masih rendah, hal ini terlihat dari masih banyaknya pegawai yang tidak mengikuti apel pagi, terlambat kembali setelah istirahat siang, serta pulang kerja lebih cepat dari jadwal yang telah ditetapkan.

Fenomena-fenomena yang terjadi serta ketidak konsistenan hasil penelitian terdahulu menjadi alasan dan motivasi dalam penelitian ini untuk mengidentifikasi dan menguji kembali pengaruh disiplin kerja dan kompensasi terhadap kinerja pegawai. Penelitian ini 


\section{Jurnal Magister Manajemen Unram Vol. 9, No 4. November 2020 NATIONALYY ACCREDITED JOURNAL - DECREE NO. 21/E/KPT/2018}

menambahkan variabel motivasi sebagai variabel intervening dalam hubungan disiplin kerja dan kompensasi dengan kinerja pegawai.

Berdasarkan uraian latar belakang diatas, tampak bahwa disiplin, kompensasi, dan motivasi memiliki peran penting dalam upaya meningkatkan kinerja pegawai, sehingga dapat dirumuskan permasalahannya sebagai berikut : Apakah disiplin kerja, kompensasi, dan motivasi berpengaruh terhadap kinerja pegawai, dan apakah ada pengaruh motivasi dalam memediasi disiplin kerja dan kompensasi dengan kinerja pegawai pada Dinas Penanaman Modal dan Pelayanan Terpadu Satu Pintu Kota Bima?.

Berdasarkan rumusan masalah tersebut maka tujuan penelitian ini adalah sebagai berikut : Untuk menganalisis pengaruh disiplin kerja, kompensasi dan motivasi kerja terhadap kinerja pegawai, untuk menganalisis pengaruh disiplin kerja dan kompensasi terhadap motivasi kerja, dan untuk menganalisis pengaruh motivasi kerja dalam memediasi disiplin kerja dan kompensasi dengan kinerja pegawai pada Dinas Penanaman Modal dan Pelayanan Terpadu Satu Pintu Kota Bima.

\section{TELAAH LITERATUR}

\section{Disiplin}

Menurut Darmawan, (2013 : 41), disiplin kerja diartikan sebagai suatu sikap, tingkah laku dan perbuatan yang sesuai peraturan dari organisasi dalam bentuk tertulis maupun tidak. Oleh karena itu dalam praktiknya bila suatu organisasi telah mengupayakan sebagian beasr peraturan-peraturan yang ditaati sebagian besar karyawannya, maka kedisiplinan telah dapat ditegakkan. Hasibuan (2013:825) mengartikan disiplin kerja sebagai kesadaran dan kesediaan seseorang menaati semua peraturan perusahaan dan norma-norma sosial yang berlaku.

\section{Kompensasi}

Menurut pendapat Fajar dan Heru (2013 : 152), Kompensasi adalah seluruh ekstrensic rewards yang diterima oleh karyawan dalam bentuk upah atau gaji, insentif atau bonus, dan beberapa tunjangan (benefits). Ekstrinsic rewards adalah imbalan yang dikontrol dan didistribusikan secara langsung oleh organisasi dan sifatnya berwujud. Hariandja (2007:244) mengatakan bahwa kompensasi adalah keseluruhan balas jasa yang diterima pegawai sebagai akibat dari pelaksanaan pekerjaan di organisasi dalam bentuk uang atau lainnya yang dapat berupa gaji, upah, bonus, insentif dan tunjangan lainnya seperti tunjangan kesehatan, tunjangan hari raya, uang makan, uang cuti dan lain-lain.

\section{Motivasi}

Perilaku seseorang pada umumnya didasarkan keinginan untuk memperoleh tujuan tertentu. Motivasi berasal dari kata latin movere yang berarti dorongan, daya penggerak atau kekuatan yang menyebabkan suatu tuindakan atau perbuatan. Kata movere dalam bahasa inggris sering disepadankan dengan motivation yang berarti pemberian motif, penimbulan motif, atau hal-hal yang menimbulkan dorongan atau keadaan yang menimbulkan dorongan (Suwarno dan Priansa, 2011,171).

Sedangkan Robbin \& Judge (2008) berpendapat bahwa motivasi sebagai proses yang menjelaskan intensitas, arah dan ketekunan seseorang individu untuk mencapai tujuanya.

\section{Kinerja}

Prestasi yang dicapai oleh pegawai tidak terlepas dari adanya manajemen dalam menciptakan kepuasan kerja. Prestasi kerja pada dasarnya merupakan kemampuan 


\section{Jurnal Magister Manajemen Unram Vol. 9, No 4. November 2020 NATIONALIY ACCREDITED JOURNAL - DECREE NO. 21/E/KPT/2018}

seseorang untuk menghasilkan produk atau jasa untuk mendorong tercapainya sasaran yang diinginkan. Menurut Wibowo (2011), kinerja berasal dari pengertian performance, adapula yang memberikan pengertian performance sebagai hasil kerja atau prestasi kerja, namun kinerja sebenarnya mempunyai makna yang lebih luas, bukan hanya hasil kerja, tetapi termasuk bagaimana proses pekerjaan berlangsung. Bangun (2012 :231), mendefinisikan kinerja sebagai hasil pekerjaan yang dicapai karyawan berdasarkan persyaratan-persyaratan pekerjaan.

Untuk mengetahui kinerja perlu diketahui factor-faktor yang dapat diukur dari apa yang dihasilkan. Mathis dan Jackson (2009) berpendapat bahwa kinerja dapat diindikasi atau diukur melalui (1) Kuantintas output, (2) Kualitas output, (3) Jangka waktu output, (4) Kehadiran ditempat kerja, (5) Sikap kooperatif.

\section{Pengembangan Hipotesis}

H1 : Disiplin kerja berpengaruh positif terhadap kinerja pegawai pada Dinas Penanaman Modal dan Pelayanan Terpadu Satu Pintu Kota Bima.

H2 : kompensasi berpengaruh positif terhadap kinerja pegawai pada Dinas Penanaman Modal dan Pelayanan Terpadu Satu Pintu Kota Bima.

H3 : motivasi kerja berpengaruh positif terhadap kinerja pegawai pada Dinas Penanaman Modal dan Pelayanan Terpadu Satu Pintu Kota Bima.

H4 : Motivasi memediasi pengaruh disiplin kerja dengan kinerja pegawai pada Dinas Penanaman Modal dan Pelayanan Terpadu Satu Pintu Kota Bima.

H5 : Motivasi memediasi pengaruh kompensasi dengan kinerja pegawai pada Dinas Penanaman Modal dan Pelayanan Terpadu Satu Pintu Kota Bima.

\section{METODE PENELITIAN}

Jenis penelitian yang digunakan adalah survey. Menurut Singarimbun dan Effendi (2006), penelitian survey dapat digunakan untuk menjelaskan (explanatory atau confirmatory) hubungan kausal dan pengujian hipotesis. Responden dalam penelitian ini adalah pegawai Dinas Penanaman Modal dan PTSP Kota Bima sebanyak 34 (tiga puluh empat) orang.

Pengukuran variabel dalam penelitian ini dilakukan dengan menggunakan skala likert. Pada penelitian ini setiap variabel disediakan 5 (lima) macam alternatif jawaban, yaitu: sangat setuju diberi skor $=5$; setuju diberi skor $=4$; kurang setuju diberi skor $=3$; tidak setuju diberi skor $=2$; sangat tidak setuju diberi skor $=1$.

Teknik pengumpulan data yang dilakukan dalam penelitian ini menggunakan metode angket yaitu teknik pengumpulan data dengan serangkaian atau daftar pertanyaan yang disusun secara sistematis untuk diisi oleh responden (Bungin, 2005:133). Instrumen yang digunakan dalam pengumpulan data ini adalah kuesioner. Analisis data yang digunakan dalam penelitian ini adalah Analisis Partial Least Square (PLS).

\section{HASIL PENELITIAN DAN PEMBAHASAN}

This section is the most important section of your article. The analysis or results of the research should be clear and concise. The results should summarize (scientific) findings rather than providing data in great detail. Please highlight differences between your results or findings and the previous publications by other researchers.

\section{Uji Reliabilitas Dan Validitas}




\section{Jurnal Magister Manajemen Unram Vol. 9, No 4. November 2020 NATIONALYY ACCREDITED JOURNAL - DECREE NO. 21/E/KPT/2018}

Berdasarkan hasil uji reliabilitas instrument yang dilakukan pada 39 responden, diketahui bahwa semua nilai Cronbach's Alpha statistik masing-masing konstruk lebih besar dari 0,7. Dapat disimpulkan bahwa seluruh item instrumen untuk masing-masing konstruk yaitu disiplin pegawai, kompensasi, motivasi, dan kinerja pegawai dinyatakan reliabel.

Berdasarkan hasil uji validitas instrumen, diketahui bahwa semua nilai korelasi antara tiap nilai instrumen dengan total nilai konstruk (r-hitung) positif dan lebih besar dari 0,5. Dapat disimpulkan bahwa seluruh item instrumen untuk tiap konstruk/variabel yaitu disiplin pegawai, kompensasi, motivasi, dan kinerja pegawai dinyatakan valid.

Metode analisis statistik inferensial yang digunakan pada penelitian ini adalah metode Partial Least Square - Structural Equation Modelling (PLS-SEM) dengan bantuan Program Smart PLS versi 3.0.

\section{Uji Validitas Convergen}

Uji validitas dalam penelitian ini yaitu convergent validity dan discriminant validity. Ukuran refleksif individual dikatakan tinggi jika berkorelasi lebih dari 0,70 $(>0,70)$ dengan konstruk yang ingin diukur. Namun demikian menurut Chin (1998) dalam Ghozali (2014:39), nilai loading factor 0,50 sampai 0,60 pada masing-masing indikator terhadap variabel konstruknya dianggap cukup sedangkan nilai Average Variance Extracted (AVE) harus lebih besar dari 0,5. Hasil algorithm tahap III menunjukkan bahwa semua indikator variabel yang tersisa memiliki nilai loading factor $>0,6$ sehingga dapat disimpulkan telah memenuhi convergent validity.

\section{Uji Validitas Discriminant}

Cara untuk menguji validitas discriminant dengan indikator refleksif pada penelitian ini yaitu dengan melihat nilai cross loading antara konstruk dengan indikatornya. Jika korelasi konstruk dengan indikatornya lebih besar dari korelasi indikator dengan konstruk lainnya maka konstruk memprediksi indikator pada blok mereka lebih baik daripada indikator pada blok lainnya, sehingga memenuhi persyaratan discriminant validity (Ghozali dan Hengky, 2015:39).

Berdasarkan hasil pengolahan data, diketahui bahwa korelasi konstruk dengan masingmasing indikatornya memiliki nilai cross loading yang lebih besar dari pada korelasi dengan indikator lainnya. Hal ini menunjukkan bahwa suatu konstruk mampu memprediksi indikator pada blok masing-masing lebih baik dibandingkan dengan indikator pada blok lainnya. Dengan demikian dapat disimpulkan bahwa indikator-indikator tersebut telah memenuhi kriteria validitas discriminant atau indikator dinyatakan valid.

\section{Uji Composite Reliability}

Pada penelitian ini uji reliabilitas dilakukan dengan menggunakan Composite Reliability. Rule of thumb yang biasa digunakan untuk menilai reliabilitas konstruk menurut Ghozali dan Hengky (2015:75) yaitu nilai composite reliability harus lebih besar dari 0,7 untuk penelitian yang bersifat confirmatory. Hasil analisis PLS algorithm untuk melihat nilai composite reliability pada penelitian ini sebagaimana disajikan pada Tabel 1. 
Tabel 1. Nilai Composite Reliability

\begin{tabular}{|l|c|c|c|}
\hline \multirow{2}{*}{ Variabel } & \multicolumn{2}{|c|}{ Rule Of Thumb } & Keterangan \\
\hline DP & Nilai & Syarat & Reliabel \\
\hline K & 0,870 & $>0,7$ & Reliabel \\
\hline M & 0,915 & $>0,7$ & Reliabel \\
\hline KP & 0,863 & $>0,7$ & Reliabel \\
\hline
\end{tabular}

Sumber : Data primer diolah

Berdasarkan Tabel 1 diketahui bahwa konstruk disiplin pegawai, kompensasi, motivasi, dan kinerja pegawai memiliki nilai composite reliability lebih besar dari 0,7. Dengan demikian dapat disimpulkan bahwa indikator-indikator dalam penelitian telah memenuhi kriteria composite reliability atau indikator dinyatakan reliabel.

\section{R square (R2)}

Nilai R square $0.67,0.33$ dan 0.19 dapat disimpulkan bahwa model kuat, moderat dan lemah (Ghozali dan Hengky, 2015:81). Nilai R square dari hasil analisis yang menggunakan metode resampling bootstrap pada level sigifikansi 5 persen sebagaimana disajikan pada Tabel 2.

Tabel 2. Nilai R square

\begin{tabular}{|l|c|c|}
\hline \multicolumn{1}{|c|}{} & R square & Kategori \\
\hline $\mathrm{M}$ & 0,688 & Kuat \\
\hline $\mathrm{KP}$ & 0,417 & Moderat \\
\hline \multicolumn{2}{|c|}{ Sumber : Data primer diolah } \\
\hline
\end{tabular}

Tabel 2 menunjukkan bahwa nilai R square Motivasi sebesar 0,688 termasuk dalam kategori kuat sedangkan R square Kinerja Pegawai sebesar 0,417 termasuk dalam kategori moderat. Hasil ini menunjukkan bahwa 68,8 persen variabel motivasi dapat dijelaskan oleh variabel disiplin pegawai dan kompensasi sedangkan 31,2 persen dijelaskan oleh faktor lain diluar variabel yang diteliti. Selain itu, 41,7 persen variabel kinerja pegawai dapat dijelaskan oleh variabel disiplin pegawai, kompensasi, dan motivasi sedangkan 58,3 persen dijelaskan oleh variabel lain diluar model yang diteliti.

\section{Pengujian Hipotesis}

Hipotesis diterima (terdukung) jika nilai t - Statistics lebih tinggi daripada nilai $\mathrm{t}$ - Tabel $(1,96)$ dan P Values < 0,05 dengan signifikansi level 5\% (one tailed). Hasil proses bootstrapping PLS dapat dilihat pada tabel berikut.

Tabel 3. Path Coefficient

\begin{tabular}{|c|c|c|c|c|c|c|}
\hline & $\begin{array}{c}\text { Original } \\
\text { sample } \\
\text { (O) }\end{array}$ & $\begin{array}{c}\text { Sample } \\
\text { Mean } \\
\mathbf{( M )}\end{array}$ & $\begin{array}{c}\text { Standard } \\
\text { Deviation } \\
\text { (STDEV) }\end{array}$ & $\begin{array}{c}\text { T Statistics } \\
(\mid \text { O/STDEV |) }\end{array}$ & $\begin{array}{c}\mathbf{P} \\
\text { Values }\end{array}$ & Ket \\
\hline $\mathrm{DP}$-> KP & 0,626 & 0,633 & 0,255 & 2,451 & 0,015 & $\begin{array}{c}\text { Hipotesis } \\
\text { diterima }\end{array}$ \\
\hline $\mathrm{K}$-> KP & 0,168 & 0,167 & 0,238 & 0,705 & 0,481 & $\begin{array}{c}\text { Hipotesis } \\
\text { ditolak }\end{array}$ \\
\hline $\mathrm{M} \mathrm{->} \mathrm{KP}$ & 0,045 & 0,052 & 0,147 & 0,309 & 0,757 & $\begin{array}{c}\text { Hipotesis } \\
\text { ditolak }\end{array}$ \\
\hline
\end{tabular}




\section{Jurnal Magister Manajemen Unram Vol. 9, No 4. November 2020 NATIONALYY ACCREDITED JOURNAL - DECREE NO. 21/E/KPT/2018}

\begin{tabular}{|c|c|c|c|c|c|c|}
\hline $\mathrm{DP}->\mathrm{M}>\mathrm{KP}$ & 0,019 & 0,024 & 0,075 & 0,248 & 0,804 & $\begin{array}{c}\text { Hipotesis } \\
\text { ditolak }\end{array}$ \\
\hline $\mathrm{K}->\mathrm{M}>\mathrm{KP}$ & 0,016 & 0,018 & 0,059 & 0,279 & 0,785 & $\begin{array}{c}\text { Hipotesis } \\
\text { ditolak }\end{array}$ \\
\hline
\end{tabular}

Sumber : Data primer diolah

\section{Pembahasan}

1. Pengaruh disiplin kerja terhadap kinerja pegawai pada Dinas Penanaman Modal dan Pelayanan Terpadu Satu Pintu Kota Bima

Berdasarkan hasil analisis data bahwa pengaruh langsung disiplin kerja (X1) terhadap kinerja karyawan (Y2) sebesar 0,626, artinya pengaruh langsung disiplin kerja (X1) terhadap kinerja pegawai adalah sebesar $62,6 \%$. Hasil uji hipotesis menunjukkan path coefficient antara disiplin kerja dengan kinerja pegawai memiliki nilai t-Statistic $(2,451)$ $>$ t-Tabel $(1,96)$, P Values $(0,015)$ dengan signifikansi 5 persen. Hasil ini menunjukkan bahwa disiplin kerja berpengaruh positif terhadap kinerja pegawai dan signifikan. Jika dalam suatu organisasi, pegawai bekerja dengan disiplin dan sesuai dengan aturan yang telah ditentukan maka semua pekerjaan dapat dilakukan dengan baik, efisien dan efektif sehingga kinerja mereka semakin meningkat dan tujuan organisasi juga dapat dicapai. Karena disiplin kerja berpengaruh positif dan signifikan terhadap kinerja pegawai, maka perlu dipertahankan dan ditingkatkan lagi agar kinerja pegawai semakin meningkat pula. Hasil penelitian ini selaras dengan hasil penelitian Halim, dkk (2016), Mahardika, dkk (2016), Putriningrum, dkk (2010 )yang menyatakan bahwa disiplin kerja yang tinggi akan meningkatkan kinerja pegawai.

2. Pengaruh kompensasi terhadap kinerja pegawai pada Dinas Penanaman Modal dan Pelayanan Terpadu Satu Pintu Kota Bima

Berdasarkan hasil analisis data bahwa pengaruh langsung Kompensasi (X2) terhadap kinerja karyawan (Y2) sebesar 0,168 artinya pengaruh langsung kompensasi (X2) terhadap kinerja pegawai adalah sebesar $16,8 \%$. Hasil uji hipotesis menunjukkan path coefficient antara kompensasi dengan kinerja pegawai memiliki nilai t-Statistic $(0,705)$ $<$ t-Tabel $(1,96)$, P Values $(0,481)$ dengan signifikansi 5 persen. Hasil ini menunjukkan bahwa kompensasi berpengaruh positif tetapi tidak secara signifikan terhadap kinerja pegawai. Kenyataan ini bisa terjadi karena pegawai menganggap bahwa kompensasi yang mereka peroleh belum mencukupi kebutuhan mereka. Hal ini juga dimungkinkan karena pegawai menganggap bahwa seberapapun kinerja mereka, mereka tetap akan mendapatkan kompensasi tersebut karena itu memang sudah menjadi hak mereka. Lain halnya apabila dalam penerapannya pemberian kompensasi dilakukan dengan selektif berdasarkan hasil kerja masing-masing individu pegawai yang ada. Kondisi ini didukung oleh jawaban responden yang didominasi jawaban "kurang setuju" pada pertanyaan "Gaji yang diterima sudah memenuhi kebutuhan", dan "Gaji yang diterima sudah sesuai beban kerja". Seharusnya pemberian kompensasi dalam suatu organisasi instansi pemerintah dirancang sedemikian rupa sehingga menciptakan iklim organisasi yang baik pula dimana pemberian kompensasi harus berdasarkan prinsipprinsip yang berkeadilan. Sehingga siapapun yang memberikan kontribusi yang maksimal terhadap organisasi akan mendapatkan kompensasi yang maksimal pula. Kondisi ini sama dengan hasil penelitian Koestartyo, dkk (2016) yang menyatakan bahwa kompensasi langsung berpengaruh positif namun tidak dapat dikatakan signifikan terhadap kinerja karyawan. Hasil penelitian ini tidak selaras dengan penelitian Zainal (2016), Mahardika (2016), serta Satedjo dan Kempa (2017) yang 
menyatakan bahwa kompensasi berpengaruh positif dan signifikan terhadap kinerja karyawan.

3. Pengaruh motivasi kerja terhadap kinerja pegawai pada Dinas Penanaman Modal dan Pelayanan Terpadu Satu Pintu Kota Bima

Berdasarkan hasil analisis data dan hasil uji hipotesis ketiga yang menyatakan motivasi kerja berpengaruh terhadap kinerja pegawai pada Dinas Penanaman Modal dan Pelayanan Terpadu Satu Pintu Kota Bima menghasilkan nilai koefisian jalur sebesar 0,045 . Hipotesis menunjukkan path coefficient antara motivasi kerja dengan kinerja pegawai memiliki nilai t-Statistic $(0,309)<\mathrm{t}$-Tabel $(1,96)$, $\mathrm{P}$ Values $(0,757)$ dengan signifikansi 5 persen. Hal ini menunjukkan bahwa motivasi kerja berpengaruh positif tetapi tidak signifikan terhadap kinerja pegawai. Ini berarti pemberian motivasi tidak mampu memberikan dorongan atau semangat kepada pegawai untuk meningkatkan kinerjanya. Kondisi ini disebabkan karena pegawai Dinas Penanaman Modal Dan Pelayanan Terpadu Satu Pintu Kota Bima yang tidak terlalu perduli dengan motivasi kerja yang mereka dapatkan. Pegawai lebih membutuhkan adanya perhatian dan perlakuan yang adil dari pimpinan serta terciptanya lingkungan kerja yang lebih nyaman. Untuk itu perlu dilakukan upaya peningkatan motivasi pegawai dengan cara pempinan memberikan perhatian dan perlakuan yang adil serta menciptakan lingkungan kerja yang membuat pegawai merasa aman dan nyaman dalam bekerja. Hasil penelitian ini mendukung penelitian Wahyuni (2016), dan Goda (2018) yang menyatakan bahwa motivasi tidak berpengaruh terhadap kinerja karyawan. Hasil penelitian ini bertentangan dengan pendapat Robbin dan Judge (2008) yang menyebutkan bahwa motivasi sebagai proses yang menjelaskan intensitas, arah dan ketekunan seseorang individu untuk mencapai tujuannya.

4. Motivasi memediasi pengaruh disiplin kerja dengan kinerja pegawai pada Dinas Penanaman Modal dan Pelayanan Terpadu Satu Pintu Kota Bima

Berdasarkan hasil analisis data bahwa pengaruh tidak langsung disiplin kerja (X1) terhadap kinerja karyawan (Y2) melalui motivasi yang menyatakan motivasi kerja memediasi pengaruh disiplin kerja (DP) dengan kinerja pegawai pada Dinas Penanaman Modal dan Pelayanan Terpadu Satu Pintu Kota Bima menghasilkan koefisien jalur sebesar 0,019 memiliki nilai t-Statistic $(0,248)<\mathrm{t}$-Tabel $(1,96)$, P Values $(0,804)$ dengan signifikansi 5 persen. Hasil ini menunjukkan bahwa motivasi kerja tidak mampu memediasi pengaruh disiplin kerja terhadap kinerja pegawai. Hasil pengujian menunjukkan pengaruh tidak langsung disiplin kerja terhadap kinerja pegawai tidak signifikan, sehingga dapat disimpulkan tidak terjadi mediasi (Y1) Artinya pengaruh tidak langsung disiplin kerja terhadap kinerja pegawai melalui motivasi sebesar $0,00 \%$ atau tidak ada sama sekali. Hasil ini menunjukkan bahwa motivasi kerja tidak mampu memediasi pengaruh disiplin kerja terhadap kinerja pegawai. Pada penelitian ini disiplin kerja berpengaruh positif dan signifikan terhadap kinerja pegawai pada Dinas Penanaman Modal dan Pelayanan Terpadu Satu Pintu Kota Bima akan tetapi apabila ada variabel motivasi yang bertindak sebagai variabel mediasi maka hasil yang diperoleh menjadi tidak berpengaruh. Hal ini dibuktikan oleh nilai koefisien jalur sebesar 0,019. Kondisi ini menunjukkan bahwa tinggi rendahnya motivasi kerja pegawai pada Dinas Penanaman Modal dan Pelayanan Terpadu Satu Pintu Kota Bima tidak akan berpengaruh terhadap hubungan antara disiplin kerja dengan kinerja pegawai pada Dinas Penanaman Modal dan Pelayanan Terpadu Satu Pintu Kota Bima.

5. Motivasi memediasi pengaruh kompensasi dengan kinerja pegawai pada Dinas Penanaman Modal dan Pelayanan Terpadu Satu Pintu Kota Bima 


\section{Jurnal Magister Manajemen Unram Vol. 9, No 4. November 2020 NATIONALYY ACCREDITED JOURNAL - DECREE NO. 21/E/KPT/2018}

Berdasarkan hasil analisis data dan hasil pengujian hipotesis yang menyatakan motivasi kerja memediasi pengaruh kompensasi dengan kinerja pegawai pada Dinas Penanaman Modal dan Pelayanan Terpadu Satu Pintu Kota Bima menghasilkan koefisien jalur sebesar 0,016 memiliki nilai t-Statistic $(0,274)<\mathrm{t}$-Tabel $(1,96)$, P Values $(0,785)$ dengan signifikansi 5 persen. Hasil ini menunjukkan bahwa motivasi kerja tidak mampu memediasi pengaruh kompensasi terhadap kinerja pegawai, Hasil pengujian pada tidak signifikan, sehingga dapat disimpulkan tidak terdapat pengaruh tidak langsung kompensasi (X2) melalui motivasi (Y1) terhadap kinerja karyawan (Y2). Motivasi merupakan suatu alat untuk menggerakkan dan mengarahkan daya dan potensi tenaga kerja agar dapat bekerja dengan produktif dan maksimal sesuai dengan kemampuan yang dimilikinya. Termotivasinya pegawai untuk bekerja dengan lebih baik akan memudahkan organisasi dalam mencapai tujuan organisasi. Namun dalam penelitian ini, motivasi diketahui berpengaruh negatif tetapi tidak signifikan dalam hubungan antara kompensasi dengan kinerja pegawai. Kondisi ini disebabkan karena motivasi kerja pegawai pada Dinas Penanaman Modal Dan Pelayanan Terpadu Satu Pintu Kota Bima masih belum maksimal yang terbukti dari masih banyaknya responden yang menjawab "kurang setuju" untuk item-item pertanyaan terkait motivasi.

\section{KESIMPULAN}

Berdasarkan hasil penelitian dan analisis data yang dilakukan pada bab pembahasan, maka dapat disimpulkan hasil penelitian sebagai berikut: Terdapat pengaruh positif dan signifikan disiplin kerja terhadap kinerja pegawai, Terdapat pengaruh positif tetapi tidak signifikan kompensasi terhadap kinerja pegawai, Terdapat pengaruh positif tetapi tidak signifikan motivasi terhadap kinerja pegawai, Motivasi kerja tidak memediasi pengaruh disiplin kerja dengan kinerja pegawai, Motivasi kerja tidak memediasi pengaruh kompensasi dengan kinerja pegawai..

Berdasarkan kesimpulan tersebut di atas, maka dapat disarankan hal-hal sebagai berikut: Pimpinan Dinas Penanaman Modal Dan Pelayanan Terpadu Satu Pintu Kota Bima terkait dengan disiplin pegawai hendaknya Kepala Dinas harus memberikan perhatian dan perlakuan yang adil kepada para pegawainya agar mereka memiliki motivasi dalam bekerja dan dapat bekerja dengan optimal, serta menerapkan sistem reward dan punishment secara konsisten. Kepada peneliti selanjutnya untuk meneliti variabel-variabel lain yang berpotensi untuk mempengaruhi kinerja pegawai Dinas Penanaman Modal dan Pelayanan Terpadu Satu Pintu Kota Bima seperti variabel lingkungan kerja fisik, kompetensi, dan gaya kepemimpinan serta menjadikan variabel motivasi sebagai variabel independen.

\section{DAFTAR PUSTAKA}

Bangun, Wilson, (2012), Manajemen Sumber Daya Manusia, Bandung, Erlangga.

Darmawan, Didit, (2013), Prinsip-Prinsip Perilaku Organisasi, Surabaya, PT. Temprina Media Grafika.

Fajar, Al Siti, dan Heru, (2013), Manajemen Sumber Daya Manusia Sebagai Dasar Memilih Keunggulan Bersaing, Sekolah Tinggi Ilmu Manajemen YKPN, Yogyakarta.

Ghozali, Imam, dan Hengky, Latan, (2015), Konsep, Teknik, Aplikasi Menggunakan Smart PLS 3.0 Untuk Penelitian Empiris, BP Undip, Semarang.

Goda V. E. M., (2018). Pengaruh Disiplin kerja, Kompensasi dan Motivasi Kerja terhadap Kinerja Karyawan (Studi Kasus Pada Karyawan Tetap Dari Semua Departemen PT. Andes Agro Investama Kendawangan, Ketapang Kalimantan Barat). 
Halim F. R., Pradhanawati A., dan Dewi R. S., (2014). Pengaruh Kompensasi, Disiplin Kerja Dan Motivasi Kerja Terhadap Kinerja Karyawan (Studi Kasus Pada Karyawan Bagian Produksi PT. Sai Apparel Industries).

Hariandja, M. T. E., (2002). Manajemen Suber Daya Manusia: Pengadaan, Pengembangan, Pengkompensasian, dan Peningkatan Produktivitas Pegawai. Jakarta, Grasindo.

Hasibuan, Malayu, S.P., (2001). Manajemen Sumber Daya Manusia, Jakarta, PT. Bumi Aksara.

Koestartyo. T. C., Yunita, S., Nugroho, A. , Pengaruh Kompensasi Terhadap Kinerja Karyawan Coffe Shop Di Surabaya, Manajemen Perhotelan. Universitas Kristen Petra, Surabaya.

Listianto, T. dan Setiadji, B., (2007). Pengaruh Motivasi, Kepuasan Dan Disiplin Kerja Terhadap Kinerja Karyawan (Studi Kasus Di Lingkungan Pegawai Kantor PDAM Kota Surakarta), Program Pasca Sarjana Universitas Muhammadiyah Surakarta.

Mahardika P. A. C., Bagia I. W., dan Yulianthini N. N., (2016). Pengaruh Kompensasi dan Disiplin Kerja Terhadap Kinerja Karyawan Pada Hotel Puri Bagus Lovina. E Journal Bisma Universitas Pendidikan Ganesha, vol. 4.

Mangkunegara, Anwar Prabu, (2009). Manajemen Sumber Daya Manusia. Bandung, Perusahaan Rosda.

Mathis, Robert L., Dan Jackson, John, H., (2011). Manajemen Sumber Daya Manusia. Terjemahan : Jimmy Sadeli, Jakarta, Salemba Empat Patria.

Putriningrum F., Ingsih K., (2010). Pengaruh Kompensasi, Motivasi, Disiplin Kerja dan Lingkungan Kerja Terhadap Kinerja Karyawan PT. Sampharindo Perdana Semarang.

Riduwan dan Kuncoro, Engkos Achmad, (2006). Cara Menggunakan Dan Memaknai Analisis Jalur (Path Analysis). Bandung, Alfabeta.

Rivai, Veithzal, (2004). Manajemen Sumber Daya Manusia Untuk Perusahaan Dari Teori Ke Praktik. Cetakan Pertama, Jakarta, PT. Raja Grafindo Persada.

Robbins, Stephen P., dan Judge, Timothy A., (2008). Perilaku Organisasi (Organizational Behaviour), Terjemahan : Diana Angelica, Ria Cahyani dan Abdul Rosyid, Buku 2, Edisi 12, Jakarta, Salemba Empat.

Satedjo, A. D., dan Kempa S, (2017). Pengaruh Kompensasi dan Disiplin Kerja Terhadap Kinerja Karyawan PT. Modern Widya Technical Cabang Jayapura. Agora vol. 5 No. 3

Singarimbun, Masri, Sofian Effendi, (2006). Metode Penelitian Survey, Edisi Revisi, LP3ES, Jakarta.

Suwatno, dan Priansa, Donni, Juni, (2011), Manajemen Sumber Daya Manusia Dalam Organisasi Publik Dan Bisnis, Bandung, Alfabeta.

Wahyuni , Sri Endang, Nurmayanti, Siti, dan Suprayetno Djoko, (2016), Pengaruh Motivasi Kerja, Kepuasan Kerja Dan Komitmen Organisasional Terhadap Kinerja Pegawai Negeri Sipil (Studi Pada Unit Pelayanan Teknis Daerah Panti Sosial Se-Pulau Lombok), Jurnal Magister Manajemen Universitas Mataram, vol. 5 No. 4

Wibowo, (2011) Manajemen Kinerja, Jakarta, Raja Grafindo Persada.

Zainal, Herawati Andi., (2016). Pengaruh Kompensasi Dan Disiplin Kerja Terhadap Kinerja Karyawan Dengan Motivasi Sebagai Variabel Intervening Pada PT. Adira Dinamika Multifinance Cabang Mamuju. 